\title{
Expression of antigen tf and galectin-3 in fibroadenoma
}

\author{
Itandehui Belem Gallegos ${ }^{1}$, Eduardo Pérez-Campos², Margarito Martinez² , Miguel Ángel Mayoral', Laura Pérez ${ }^{1}$, \\ Sergio Aguilar ${ }^{1}$, Edgar Zenteno ${ }^{3}$, Maria del Socorro Pina ${ }^{1}$ and Pedro Hernández ${ }^{1 *}$
}

\begin{abstract}
Background: Fibroadenomas are benign human breast tumors, characterized by proliferation of epithelial and stromal components of the terminal ductal unit. They may grow, regress or remain unchanged, as the hormonal environment of the patient changes. Expression of antigen TF in mucin or mucin-type glycoproteins and of galectin-3 seems to contribute to proliferation and transformations events; their expression has been reported in ductal breast cancer and in aggressive tumors.

Findings: Lectin histochemistry, immunohistochemistry, and immunofluorescence were used to examine the expression and distribution of antigen TF and galectin-3. We used lectins from Arachis hypogaea, Artocarpus integrifolia, and Amaranthus lecuocarpus to evaluate TF expression and a monoclonal antibody to evaluate galectin-3 expression. We used paraffin-embedded blocks from 10 breast tissues diagnosed with fibroadenoma and as control 10 healthy tissue samples. Histochemical and immunofluorescence analysis showed positive expression of galectin-3 in fibroadenoma tissue, mainly in stroma, weak interaction in ducts was observed; whereas, in healthy tissue samples the staining was also weak in ducts. Lectins from A. leucocarpus and A. integrifolia specificaly recognized ducts in healthy breast samples, whereas the lectin from A. hypogaea recognized ducts and stroma. In fibroadenoma tissue, the lectins from A. integrifolia, A. Hypogaea, and A. leucocarpus recognized mainly ducts.
\end{abstract}

Conclusions: Our results suggest that expression of antigen TF and galectin-3 seems to participate in fibroadenoma development.

Keywords: Antigen TF, Galectin-3, Fibroadenoma, Breast cancer, Plant lectins

\section{Background}

Fibroadenomas are benign breast tumors commonly found in young women. Fibroadenoma is a biphasic lesion of the breast characterized by proliferation of both epithelial and stromal components of the terminal ductal unit. Proliferation of stromal cells is commonly considered the primary event in the development of a fibroadenoma, followed by secondary proliferation of epithelial cells [1]. Most fibroadenomas are considered to be the result of hyperplastic processes involving connective tissue of lobular units [2]. Fibroadenomas' development is heterogeneous, since they may grow, regress, or remain unchanged as the hormonal environment ofthe patient changes, but

\footnotetext{
*Correspondence: fuegoblanco136@yahoo.com.mx

${ }^{1}$ Centro de Investigaciones en Ciencias Medicas y Biológicas Facultad de Medicina, Universidad Autónoma Benito Juárez de Oaxaca, 68020, Oaxaca, Mexico

Full list of author information is available at the end of the article
}

most stop growing after reaching 2 to $3 \mathrm{~cm}$ in diameter [3], moreover, with aging, the stroma becomes less cellular and increases its hyalinization [4]. Occurrence in young women and sclerotic involution in the elderly suggest a hormonal responsiveness of fibroadenomas [1].

O-glycosylation plays an important role in the biological activity of glycoproteins involved in controlling cell differentiation [5,6]. Alterations in glycosylation of cell membrane glycocongugates in neoplastic lesions from a variety of organs, including lung, stomach, ovary, skin and endometrium, have been reported $[7,8]$. Abnormal O-glycosylation, especially in mucin and mucin type glyproteins, results in exposure of the peptide core, as well as in the exposure of the normally cryptic core TF (Galß1-3GalNAco1-O-Ser/Thr) antigen [9], which is distributed discontinuously along the peptide backbone, and premature sialylation can occur leading to formation of antigens related to cancer progression [10].

\section{Biomed Central}


Lectins are proteins that recognize carbohydrates or precipitate glycoconjugates and they are important tools for oligosaccharide characterization as well as for isolation of cellular populations [11]. Galectin-3 is a $31 \mathrm{kDa}$ protein member of the beta-galactoside-binding proteins; it is an intracellular and extracellular lectin that interacts with intracellular glycoproteins, cell surface molecules, and extracellular matrix proteins. Galectin-3 is expressed widely in epithelial and immune cells and its expression is correlated with cancer aggressiveness and metastasis [12]. The aim of this study was to determine, by histochemsitry, the over-expression of antigen TF and galectin-3 in fibroadenoma and healthy breast tissues, using specific lectins for antigen $\mathrm{TF}$ and antigalectin-3 antibody, to understand better the potential role of O-glycosylation in fibroadenomas' progression.

\section{Findings}

\section{Reagents}

Biotynilated lectins from Arachis hypogaea and Artocarpus integrifolia were obtained from Vector Laboratories (Burlingame, CA USA). Lectin from Amaranthus leucocarpus (ALL) was purified by affinity chromatography using a column containing stroma from human O-desialylated erythrocytes entrapped in Sephadex G-25 (Upssula Sweden), as described previously [13]. ALL was labeled with the $\mathrm{N}$-hydroxisuccinimide ester of biotin (Bio-Rad Inc., Richmond, CA, USA) at a label/protein ratio of 2:1 [14] Avidin-peroxidase, sugars, and chemical reagents were from (Sigma Chemical Co, St. Louis, MO, USA), 3-amino-9-ethyl-carbazole (AEC) kit used as substrate for peroxidase was obtained from Vector Laboratories. Biotin-labeled mouse anti-galectin-3 was obtained from Invitrogen (Carlsbad, CA USA).

\section{Source of tissues}

Ten paraffin-embedded blocks from breast tissues diagnosed with fibroadenoma were kindly donated by Paulina Leyva, from the Pathology Department of the School of Medicine, UABJO, Oaxaca, Mexico. Ten healthy control tissue samples were obtained from cosmetic procedures at the Plastic Surgery service from the Mexican Institute of Social Security (IMSS, for its initials in Spanish), Mexico.

\section{Ethical approval}

The study protocol was approved by the Institutional Review Board of Research of the Medical School of UABJO.

\section{Immunohistochemistry}

Paraffin-embedded blocks from fibroadenoma and normal breast tissues, the latter used as controls, were cut in $6-\mu \mathrm{m}$-thick sections. Sections were incubated with each biotin-labeled lectin $(1 \mu \mathrm{g} / \mathrm{ml})$ or monoclonal anti-
Table 1 Interaction of lectin or antibodies with all the healthy and fibroadenoma breast samples* used in this study

\begin{tabular}{lcccccc}
\hline ANTIBODY & \multicolumn{2}{c}{ NORMAL } & & \multicolumn{2}{c}{ FIBROADENOMA } \\
\cline { 2 - 3 } & + & - & & + & - \\
\hline Anti galectin-3 & 10 & 0 & & 10 & 0 \\
\hline Arachis hypogaea & 10 & 0 & & 10 & 0 \\
\hline Artocarpus integrifolia & 6 & 4 & & 8 & 2 \\
\hline Amaranthus leucocarpus & 6 & 4 & & 8 & 2 \\
\hline
\end{tabular}

$\mathrm{N}=10$ healthy and 10 fibroadenoma samples evaluated.

galectin-3 antibody (dilution 1:100), overnight at $4^{\circ} \mathrm{C}$. After incubation, the slides were washed with PBS, pH 7.4 , and covered with $300 \mu \mathrm{l}$ of $5 \%$ skimmed milk in PBS, $\mathrm{pH} 7.4$, and incubated for $12 \mathrm{~h}$ at $4^{\circ} \mathrm{C}$. Then, after washing with $\mathrm{PBS}, \mathrm{pH} 7.4$, the samples were labeled with streptavidin-peroxidase (1:1000 in PBS) for $1 \mathrm{~h}$ at $37^{\circ} \mathrm{C}$. Unbound conjugate was removed by washing six times with PBS. The binding of lectins or antibody was revealed by incubating with 3-amino-9-ethyl-carbazole (AEC), following instructions of manufacturer (Invitrogen), during $15 \mathrm{~min}$ at $37^{\circ} \mathrm{C}$. The reaction was stopped by washing with water. Slides were observed with an AXIOSCOP 40 microscope (Zeiss, Germany) equipped with a digital camera AXIOCAM MRC (Zeiss) and micrographs were analyzed with the AXIOVISION 4.3 Software (Zeiss).

\section{Immunofluorescence}

Double labeling of slides was performed as follows: Tissue samples were labeled with lectins $(1 \mu \mathrm{g} / \mathrm{ml})$ overnight at $4^{\circ} \mathrm{C}$ and monoclonal anti-galectin-3 antibody used at 1:100 following the same procedure as previously described, except that lectin binding was indirectly recognized with extravidin-FITC conjugated (Sigma Chemical Co.) and visualized using a green filter. Anti-galectin antibodies were revealed with extravidinred-X conjugate (Invitrogen) and visualized using a red filter. Slides were observed with an AXIOSCOP 40 microscope (Zeiss), equipped with a digital camera AXIOCAM MRC (Zeiss) and micrographs were analyzed with the AXIOVISION 4.3 Software (Zeiss).

Table 2 Staining of normal and fibroadenoma using antigalectin-3 antibody and lectins*

\begin{tabular}{lll}
\hline ANTIBODY & NORMAL & FIBROADENOMA \\
\hline Anti-Galectin-3 & 1 & 2 \\
\hline Arachis hypogaea & 2 & 1 \\
\hline Artocarpus integrifolia & 1 & 1 \\
\hline Amaranthus leucocarpus & 1 & 2
\end{tabular}

*The presence and absence of staining in breast samples was recorded as follows: No stain, 0; ductal stain, 1; ductal and estromal stain, 2. 

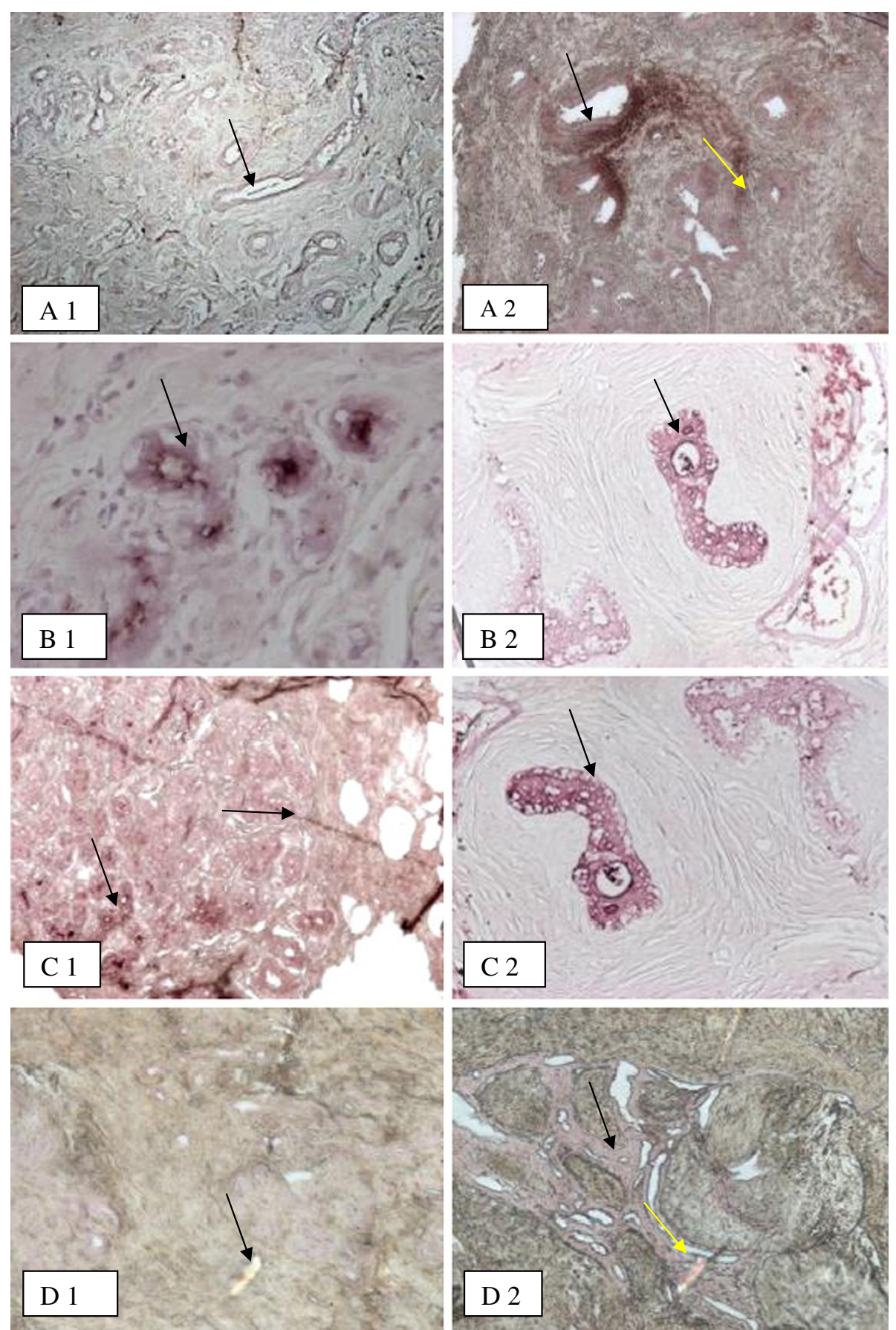

Figure 1 Lectin and anti-galectin-3 histochemistry in healthy breast and fibroadenoma samples. Amaranthus leucocarpus recognizes ducts in healthy breast samples (A1): in fibroadenoma, Amaranthus leucocarpus lectin recognizes ducts and stroma cells (A2). Artocarpus integrifolia lectin recognizes ducts in healthy (B1) and fibroadenoma samples (B2). Arachis hypogaea recognizes ducts in healthy (C1) and in fibroadenoma samples (C2). Anti-galectin-3 antibody depicts weak staining in ducts of healthy samples (D1); in fibroadenoma, the antibody recognizes ducts and stroma cells (D2) Arrows indicate the lectin and antibody binding sites. Black arrow indicates ducts site of lectin or antibody binding. Yellow arrow indicates stroma site of lectin or antibody binding. Micrographs are in 10X. 

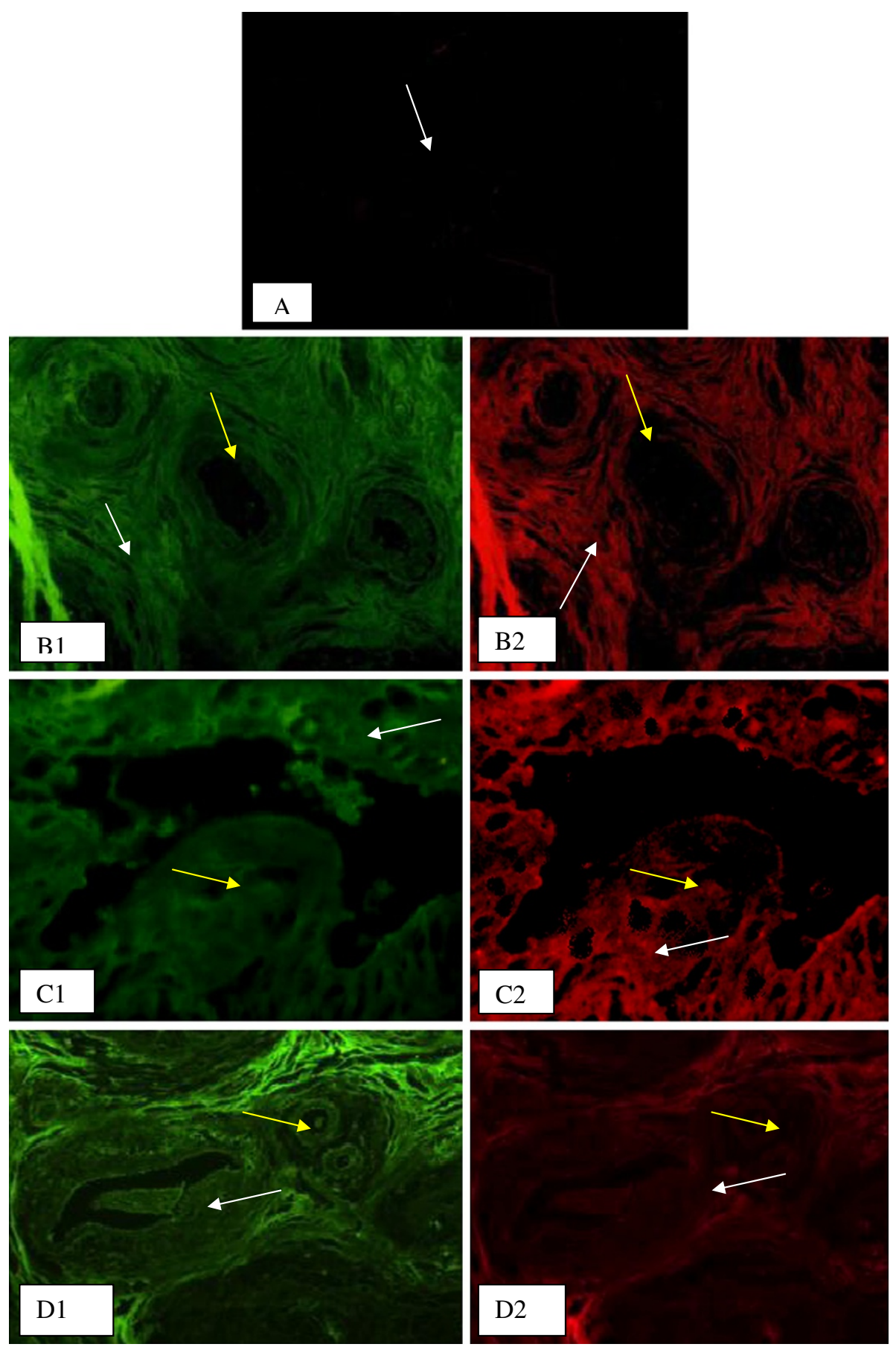

Figure 2 Lectin and anti-galectin-3 double labeling histochemistry, in healthy breast and fibroadenoma samples. Weak staining with anti-galectin-3 was observed in healthy samples (A). Artocarpus integrifolia lectin recognizes ducts and stroma in healthy breast samples (B1). Arachis hypogaea recognizes ducts and stroma in healthy samples (C1). Amaranthus leucocarpus recognizes ducts and stroma in healthy breast samples (D1). In fibroadenoma, anti-galectin-3 recognizes ducts and stroma (B2) (C2) (D2). White arrow indicates ducts site of lectin or antibody binding. Yellow arrow indicates stroma site of lectin or antibody binding. Micrographs 10X. 


\section{Lectin specificity}

To determinate the lectins' specificity in control breast epithelium and fibroadenomas, lectin histochemistry and immunoflourescence assays were performed using lectins incubated with $200 \mathrm{mM}$ of their specific monosaccharide (N-acetyl-D-galactosamine) $30 \mathrm{~min}$ before use.

\section{Statistical analysis}

Fisher's exact test using Woolf's approximation was performed using GraphPad InStat version 3.00, GraphPad Software, San Diego California USA.

\section{Results}

\section{Lectins and anti galectin-3 histochemistry}

Numbers of samples positive and negative to either lectins or antibody are summarized in Table 1 . As indicated in Table 2, in control samples, obtained from healthy tissues. Amaranthus leucocarpus lectin (ALL) recognized ducts in healthy breast samples (Figure 1. A1); whereas, in fibroadenoma tissues, this lectin recognized ducts and stroma cells (Figure 1. A2). A. integrifolia lectin recognized ducts in healthy (Figure 1. B1) and fibroadenoma samples equally well (Figure 1. B2). A. hypogaea recognized ducts in healthy (Figure 1. C1) and fibroadenoma samples (Figure 1. C2). Anti-galectin-3 antibody showed a weak staining in ducts of healthy samples (Figure 1. D1); however, in fibroadenoma tissue, the antibody recognized ducts and stroma cells (Figure 1. D2).

\section{Immunofluorescence}

Lectins and anti-galectin-3, in double labeling immunoflourescence, in healthy breast and fibroadenoma samples, showed weak staining with anti-galectin-3 in healthy samples (Figure 2. A). A. integrifolia lectin recognized ducts and stroma in healthy (Figure 2. B1) and in fibroadenoma samples; whereas antigalectin-3 recognized ducts and stroma (Figure 2. B2). A. hypogaea recognized ducts and stroma in healthy samples (Figure 2. C1); whereas, in fibroadenoma samples, anti-galectin-3 recognized ducts and stroma (Figure 2. C2). Amaranthus leucocarpus recognized ducts and stroma in healthy breast samples (Figure 2. D1); in fibroadenoma samples, antigalectin-3 recognized ducts and stroma (Figure 2. D2). A. integrifolia lectin recognized luminal cells of ducts in fibroadenoma (Figure 3. A1). No interaction with luminal cells was observed in fibroadenomas using anti-galectin-3 antibody (Figure 3. A2). Lectins and anti-galectin-3 antibody staining showed no co-localization.

\section{Statistical results}

Lectins and using anti-galectin-3 antibody were not statistically significant

\section{Discussion}

A fibroadenoma is a benign tumor with stromal and epithelial elements $[15,16]$; however, it has been associated with increased risk for breast cancer, particularly when associated with fibrocystic changes, proliferative breast disease, or a family history of breast cancer [17]. Recently, studies in alterations of the membrane's protein glycosylation have been performed to understand better the changes taking place during cellular transformation to cancer $[18,19]$. Lectins, due to their higher specificity for carbohydrates and glycoconjugates, have been used to detect glycosylation changes in cancer cells [20-22]. In this work, we studied the glycosylation pattern in fibroadenomas using lectins with specificity for N-acetyl-Dgalactosamine linked to protein or lipids. In fibroadenoma samples, lectins recognized different cytoplasmic regions from those recognized by antibodies, indicating that some cells express mucin-type O-glycans. In dermal carcinoma, as well as in carcinoma in situ [23], Arachis hypogaea, Artocarpus integrifolia, and Amaranthus leucocarpus lectins recognize the Galß1-3GalNAc or TF antigen (Thomsen-Friedenreich antigen). Our results showed that the A. leucocarpus lectin recognized ducts in control

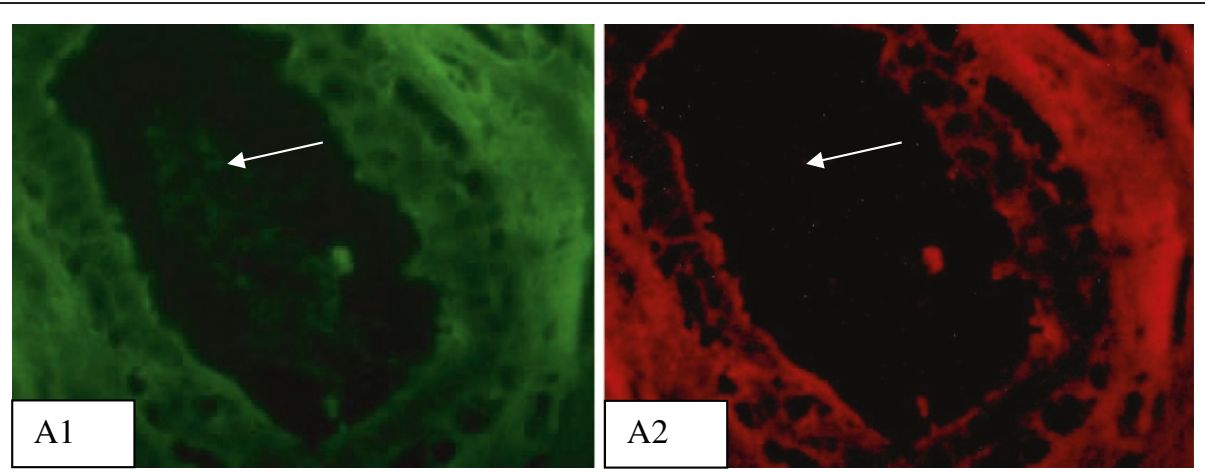

Figure 3 Lectin and anti-galectin-3 double labeling histochemistry in fibroadenoma samples. Artocarpus integrifolia lectin recognizes luminal cells of ducts (A1). No interaction with luminal cells was observed in fibroadenoma using anti-galectin-3 (A2). White arrow indicates ducts site of lectin or antibody binding. Micrographs (40X). 
samples; whereas, in fibroadenoma, it recognized ducts and some stromal cells. The recognition pattern of Arachis hypogaea was the same in control and fibroadenoma tissues, i.e., the lectin recognized ducts. A. intergrifolia recognized ducts in control samples, but in fibroadenoma the lectin recognized luminal cells. The ability of lectins to bind carbohydrates depends on their 3-D structure [24,25] and on their capacity to detect subtle variations in the conformation of carbohydrate structures of cell surfaces [25]. This ability could be explained by the variability in the size of the carbohydrate-recognition domain (CDR) and the variability in quaternary association [25]. Interestingly, the CDR of A. leucocarpus lectin recognizes GalNAc residues when they are spaced out in glycan structures, whereas GalNAc residues arranged in clusters prevent interaction with the lectin [26]. These glycans have been related with cervical cancer development [27] and are present in fibroadenomas [28], whereas Artocarpus integrifolia lectin can recognize clusters of TF antigen.

Galectin-3 is a naturally occurring galactoside-binding lectin expressed intra- and extra-cellularly by many cell types [29]. It has been shown that galectin-3 expression is increased in patients with breast, gastrointestinal, or lung cancer [30]. Moreover, higher galectin-3 expression has been shown in patients with metastatic disease than in patients with localized tumors [31]. Cytoplasmic galectin-3 is known to be anti-apoptotic, whereas nuclear galectin-3 promotes pre-mRNA splicing [32]. Cell surface galectin-3 is involved in various cell-cell and cell-matrix interactions $[33,34]$ and enhances cancer cell adhesion and invasion through basement membrane by interacting with extracellular matrix proteins such as fibronectin, collagen, or laminin [35,36]. Galectin-3 expressed on the endothelial cell surface has been shown to promote adhesion of breast cancer cells to the endothelium by interaction with cancer- associated Thomsen-Friedenreich antigen cell surface molecules $[37,38]$. TF antigen is the core I structure of mucin-type $O$-linked glycans, but in its simplest nonsialylated form, as non-extended form it acts as an oncofetal antigen, and its presence/expression is increased in malignant and premalignant epithelia [39,40]. A weak interaction with ducts, in healthy samples was observed when antigalectin-3 antibody was used, whereas, in fibroadenoma samples, the interaction was observed in ducts and stromal cells.

\section{Conclusions}

Our results suggest that galectin-3 and Galß1,3-GalNAC glycosylated glycoproteins represent important elements in fibroadenomas' development, reinforcing the notion that lectins constitute a very useful tool for the study of breast cancer.

\section{Abbreviations}

AEC: 3-amino-9-ethyl-carbazole; CDR: Carbohydrate-recognition domain; FITC: Fluorescein isothiocyanate; Gal: Galactose; GalNAc:

$\mathrm{N}$-acetylgalactosamine; PBS: Phosphate buffered saline; Ser: Serine; Thr: Threonine; TF: Thomsen-Friedenreich antigen; UABJO: Universidad Autónoma "Benito Juárez" de Oaxaca; UNAM: Universidad Autónoma de México; USA: United Satates of America.

\section{Competing interests}

The authors declare that they have no competing interest

\section{Authors' contributions}

IBG processed the samples, analyzed data, and reviewed the literature. EP analyzed data and reviewed the manuscript. PH performed literature review, drafted most of the manuscript. EZ analyzed data and reviewed the manuscript. SA, MM, MAM and LP reviewed the manuscript. All authors have read and approved the final manuscript.

\section{Acknowledgements}

This work was supported by PTC-FMC-14 and Programa de Fortalecimoento de Cuerpos Academicos 2011 UABJO-CA-043. We are especially grateful to Paulina del Carmen Leyva Bohorquez (Pathology Laboratory of the Mexican Institute of Social Security, Oaxaca, Mexico) and Claudia Hernandez Valverde of the Plastic Surgery service of the Mexican Institute of Social Security, for technical assistance.

\section{Author details}

${ }^{1}$ Centro de Investigaciones en Ciencias Medicas y Biológicas Facultad de Medicina, Universidad Autónoma Benito Juárez de Oaxaca, 68020, Oaxaca, Mexico. ${ }^{2}$ Unidad de Investigación en Bioquímica, Instituto Tecnológico de Oaxaca, Oaxaca, Mexico. ${ }^{3}$ Laboratorio de Inmunología, Departamento de Bioquímica, Facultad de Medicina, Universidad Nacional Autónoma de México, Mexico 04510, Mexico.

Received: 30 August 2012 Accepted: 18 December 2012 Published: 24 December 2012

\section{References}

1. Sapino A, Bosco M, Cassoni P, Castellano I, Arisio R, Cserni G, Tos AP, Fortunati N, Catalano MG, Bussolati G: Estrogen receptor-beta is expressed in stromal cells of fibroadenoma and phyllodes tumors of the breast. Mod Pathol 2006, 19:599-606.

2. Kuijper A, Buerger $H$, Simon R, Schaefer KL, Croonen A, Boecker W, Van der Wall $E$, Van Diest PJ: Analysis of the progression of fibroepithelial tumours of the breast by PCR-based clonality assay. J Pathol 2002, 197:575-581.

3. Dixon JM: Cystic disease and fibroadenoma of the breast: natural history and relation to breast cancer risk. Br Med Bull 1991, 47:258-271.

4. Martin PM, Kuttenn F, Serment H, Mauvais-Jarvis P: Studies on clinical, hormonal and pathological correlations in breast fibroadenomas. J Steroid Biochem 1978, 912:1251-1255.

5. Bulmer JC: Lectin hystochemistry of pregnant rat uterine tissues. J Anat 1996, 188:197-205.

6. Tanda N, Mori S, Nose M, Saito T, Song ST, Sato A: Expression of Phaseolus vulgaris leukoagglutinin-binding oligosaccharides in oral squamous cell carcinoma: possible association with the metastatic potential. Pathol Int 1996, 46:639-645.

7. Eckart L, Haleh N: Lectin histochemistry of the resected adenocarcinoma of the lung, Helix pomatia agglutinin binding is an independent prognostic factor. Am J Pathol 2002, 160:1001-1008.

8. Kamura $V$, Shanthi $P$, Madhavan M: Lectin binding patterns in benign and malignant lesions of the breast. Indian J Pathol Microbiol 1992, 35:289-297.

9. Yamashita $Y$, Chung YS, Horie R, Kanagi R, Sowa M: Alterations in gastric mucin with malignant transformation: novel pathway for mucin synthesis. J Natl Cancer Inst 1995, 87:441-446.

10. Shuman J, Dongxu Q, Koganty R, Longenecker R, Campbell P: Glycosylation versus conformational preferences of cancer associated mucin core. Glyconconj J 2000, 17:835-848.

11. Gorocica P, Lascurain R, Hemandez P, Porras F, Bouquelet S, Vazquez L, Zenteno E: Isolation of the receptor for Amaranthus leucocarpus lectin from murine peritoneal macrophages. Glycoconj J 1998, 8:809-814. 
12. Takenaka Y, Fukumori T, Raz A: Galectin-3 and metastasis. Glycoconj J 2004, 19:543-548

13. Zenteno E, Ochoa JL: Isolation and characterization of Amaranthus leucocarpus lectin. Phytochemistry 1983, 27:313-317.

14. Savage D, Mattson G, Desai S, Nielander G, Morgensen S, Coklin E: Avidin-biotin chemistry: a handbook. Rockford, IL: Pierce Chemical Co; 1992:1-50.

15. Brentani MM, Pacheco MM, Oshima CT: Steroid receptors in breast angiosarcoma. Cancer 1983, 51:2105-2111.

16. De Luca LA, Traiman P, Bacchi CE: An unusual case of malignant cystosarcoma phyllodes of the breast. Gynecol Oncol 1986, 24:91-96.

17. Dupont WD, Page DL, Parl FF: Long term risk of breast cancer in women with fibroadenoma. N Eng J Med 1994, 331:10-15.

18. Nakayama T, Watanabe M, Katsumata T, Teramoto T, Kitajima M: Expression of Sialyl Lewis ${ }^{\mathrm{a}}$ as a new prognostic factor for patients with advanced colorectal carcinoma. Cancer 1995, 75:2051-2056.

19. Rajpert-De Meyts E, Poll SN, Goukasian I, Jeanneau C, Herlihy AS, Bennett EP, Skakkebaek NE, Clausen H, Giwercman A, Mandel U: Changes in the profile of simple mucin-type O-glycans and polypeptide GalNAc-transferases in human testis and testicular neoplasms are associated with germ cell maturation and tumour differentiation. Virchows Arch 2007, 4:805-814.

20. Goldstein IJ, Hughes RC, Monsigny M, Osawa T, Sharon N: What should be called a lectin? Nature 1980, 28:286.

21. Lis H, Sharon N: Lectins as molecules and as tools. Ann Rev Biochem 1986, 55:35-67.

22. Karuna $V$, Shanthi $P$, Madhavan M: Lectin binding patterns in benign and malignant lesions of the breast. Indian J Pathol Microbiol 1992, 4:289-297.

23. Cui Y, Noguchi H, Kiguchi K, Aoki D, Susumu N, Nozawa S, Kawakami H, Hirano H, Iwamori M: Human cervical epidermal carcinoma-associated intracellular localization of glycosphingolipid with blood group A type 3 chain. Jpn J Cancer Res 1993, 84:664-672.

24. Weiss IW, Drickramer K: Structural basis of the lectin-carbohydrate recognition. Annu Rev Biochem 1996, 65:441-473.

25. Sharma $V$, Surolia A: Analysis of carbohydrate recognition by legume lectin: size of the combining site loops and their primary specificity. J Mol Biol 1997, 267:433-445.

26. Hernández $P$, Tetaert $D$, Vergoten $G$, Debray H, Jimenez MC, Fernández G, Agundis C, Degand P, Zenteno E: Specificity of Amaranthus leucocarpus syn hypocondriacus lectin for O-glycopeptides. Biochim Biophys Acta 2004, 1674:282-290.

27. Santaella A, Gallegos B, Perez E, Zenteno E, Hernández P: Use of Amaranthus leucocarpus lectin to differentiate cervical dysplasia (CIN). Prep Biochem Biotechnol 2007, 37:219-228.

28. Gallegos B, Pérez-Campos E, Martinez R, Leyva P, Martinez M, Hernández R, Pina S, Hernández C, Zenteno E, Hernández P: O-glycosylation expression in fibroadenoma. Prep Biochem Biotechnol 2010, 40:1-12.

29. Liu FT, Rabinovich GA: Galectins as modulators of tumour progression. Cancer 2005, 5:29-41.

30. lurisci I, Tinari N, Natoli C, Angelucci D, Cianchetti E, lacobelli S: Concentrations of galectin-3 in the sera of normal controls and cancer patients. Clin Cancer Res 2000, 6:1389-1393.

31. Yang RY, Hsu DK, Liu FT: Expression of galectin-3 modulates T-cell growth and apoptosis. Proc Natl Acad Sci USA 1996, 93:6737-6742.

32. Dagher SF, Wang JL, Patterson RJ: Identification of galectin-3 as a factor in pre-mRNA splicing. Proc Natl Acad Sci USA 1995, 92:1213-1217.

33. Hughes RC: Galectins as modulators of cell adhesion. Biochimie (Paris) 2001, 83:667-676

34. Rabinovich GA, Baum LG, Tinari N, Paganelli R, Natoli C, Liu FT, lacobelli S: Galectins and their ligands: amplifiers, silencers or tuners of the inflammatory response? Trends Immunol 2002, 23:313-320.

35. Ochieng J, Platt D, Tait L, Hogan V, Raz T, Carmi P, Raz A: Structure-function relationship of a recombinant human galactoside-binding protein. Biochemistry 1993, 32:4455-4460.

36. Takenaka Y, Fukumori T, Raz A: Galectin-3 and metastasis. Glycoconj 2004, 19:543-549.

37. Glinsky W, Glinsky GV, Glinskii OV, Huxley VH, Turk JR, Mossine W, Deutscher SL, Pienta KJ, Quinn TP: Intravascular metastatic cancer cell homotypic aggregation at the sites of primary attachment to the endothelium. Cancer Res 2003, 63:3805-3811.
38. Zou J, Glinsky W, Landon LA, Matthews L, Deutscher SL: Peptides specific to the galectin-3 carbohydrate recognition domain inhibit metastasisassociated cancer cell adhesion. Carcinogenesis 2005, 6:309-318.

39. Glinsky W, Huflejt ME, Glinsky GV, Deutscher SL, Quinn TP: Effects of Thomsen-Friedenreich antigen-specific peptide P-30 on betagalactoside-mediated homotypic aggregation and adhesion to the endothelium of MDA-MB-435 human breast carcinoma cells. Cancer Res 2000, 60:2584-2588.

40. Glinsky W, Glinsky GV, Rittenhouse-Olson K, Huflejt ME, Glinskii OV, Deutscher SL, Quinn TP: The role of Thomsen-Friedenreich antigen in adhesion of human breast and prostate cancer cells to the endothelium. Cancer Res 2001, 61:4851-4857.

\section{doi:10.1186/1756-0500-5-694}

Cite this article as: Gallegos et al:: Expression of antigen tf and galectin3 in fibroadenoma. BMC Research Notes 2012 5:694.

\section{Submit your next manuscript to BioMed Central and take full advantage of:}

- Convenient online submission

- Thorough peer review

- No space constraints or color figure charges

- Immediate publication on acceptance

- Inclusion in PubMed, CAS, Scopus and Google Scholar

- Research which is freely available for redistribution

Submit your manuscript at www.biomedcentral.com/submit
C) Biomed Central 